\title{
LAGU HIMNE KARYA CHARLES WESLEY DAN RELEVANSINYA BAGI PENGINJILAN MASA KINI
}

\author{
${ }^{1}$ Kezia Inriyani Pobuti ; ${ }^{2}$ Rohani Siahaan \\ ${ }^{1}$ Teologi, Konsentrasi Musik Gerejawi, Sekolah Tinggi Filsafat Jaffray Makassar \\ ${ }^{2}$ Teologi, Konsentrasi Musik Gerejawi, Sekolah Tinggi Filsafat Jaffray Makassar
}

keziapobuti10@gmail.com

\begin{abstract}
The writing of this scientific work was motivated to see the role of a song in evangelism, carried out by the Wesley brothers. The Wesley brothers were one of the ecclesiastical figures who had a large role in developing evangelistic services in England. Each of the Wesley brothers has its role when running services. John Wesley is famous for his constructive preaching and discipline in faith in Jesus Christ, while Charles Wesley is famous for writing song lyrics. The research method used in writing this thesis is to use qualitative methods. And to do the research method, the things that will be done are: First, data collection and collection through books, journals, and online thesis related to the title discussed in this paper. Second, observation of songs by Charles Wesley. In this scientific work, the author tries to prove that the role of singing in the Wesley evangelization of brothers plays the extent to which the song was created by Charles Wesley, supporting John Wesley's sermon. Each poem contains a profound meaning in moving the congregation's hearts so that singing can make the church repent and experience the confirmation of faith in Jesus Christ.
\end{abstract}

Keywords: Charles Wesley, John Wesley, Song, Evangelism.

\begin{abstract}
ABSTRAK
Penulisan karya ilmiah ini dilatar belakangi dengan sebuah tujuan untuk melihat lagu hymn karya Charles Wesley memiliki relevansi di dalam sebuah penginjilan, yang dilakukan oleh Wesley bersaudara. Wesley bersaudara merupakan salah satu tokoh gerejawi yang mempunyai peran besar dalam berkembangnya pelayanan penginjilan di Inggris. Masing-masing diantara Wesley bersaudara mempunyai peran tersendiri ketika menjalankan pelayanan. John Wesley terkenal dengan khotbahnya yang membangun dan displin dalam iman kepada Yesus Kristus, sedangkan Charles Wesley terkenal dengan kemampuannya dalam menulis lirik lagu. Metode penelitian yang digunakan dalam penulisan karya ilmiah ini adalah dengan menggunakan metode kualitatif. Dan untuk melakukan metode penelitian tersebut hal yang akan dilakukan, yaitu: Pertama, pengambilan dan pengumpulan data melalui buku, jurnal, dan skripsi online yang berkaitan dengan judul yang dibahas dalam karya tulis ini. Kedua, observasi lagu-lagu ciptaan Charles Wesley. Dalam karya ilmiah ini, penulis mencoba untuk membuktikan bahwa lagu hymn karya Charles Wesley mempunyai relevansi di dalam penginjilan Wesley bersaudara berperan sejauh mana nyanyian yang diciptakan oleh Charles Wesley, mendukung khotbah dari John Wesley, dan pelayanan penginjilan yang dikerjakan menghasilkan makna baru. Setiap syair mengandung makna yang mendalam dalam menggugah hati jemaat, sehingga lewat nyanyian mampu membuat jemaat bertobat, dan mengalami peneguhan iman di dalam Yesus kristus.
\end{abstract}

Kata Kunci: Charles Wesley, John Wesley, Nyanyian, Penginjilan 


\section{PENDAHULUAN}

Musik merupakan satu aktivitas yang tidak pernah jauh atau bahkan tidak terlepaskan dari kehidupan manusia. Dari waktu ke waktu, sejak manusia mengenal musik, dalam keberadaannya musik terus mengalami perkembangan dan peningkatan. Hal ini seiring dengan kemajuan zaman, kecanggihan teknologi, ditambah lagi dengan kebutuhan para penikmat musik. Pemusik mengenal banyak jenis musik yang ada, serta peruntukannya masing-masing. Musik secara umum mampu menggambarkan emosi seseorang, baik pemain atau penyanyi, atau bahkan pendengar dari sebuah permainan musik. Bagi umat kristen, musik mempunyai peran yang besar dalam peribadatan umat. ${ }^{1}$ Salah satu yang termasuk di dalamnya adalah nyanyian. Nyanyian secara umum merupakan ungkapan hati seseorang yang dituangkan dalam bentuk nada, syair, melodi, ritme, dan lain sebagainya. ${ }^{2}$ Sedangkan Nyanyian rohani merupakan sarana umat untuk mengagungkan, dan membawa jemaat masuk dalam penyembahan kepada Allah. ${ }^{3}$

Sekitar abad 17 merupakan puncak perkembangan musik gereja. Berbagai jenis nyanyian rohani berkembang pesat, salah satunya adalah himne yang berupa motet; bahkan mazmur juga menjadi salah satu bentuk himne yang mampu membuat jemaat pada saat itu merasakan hadirat Tuhan. ${ }^{4}$ Jika musik gereja bahkan nyanyian himne pada abad itu mampu mengubah jemaat Tuhan, maka bisa dilihat bahwa nyanyian pada saat ini pun juga mempunyai kuasa untuk menyatakan kehendak Tuhan bagi setiap umat-Nya. Terlepas dari berapa lama sebuah lagu diciptakan, arti bahkan kisah dari sebuah lagu itulah yang akan menjadikan lagu tersebut mampu dikenang oleh orang banyak. Dengan beragamnya jenis nyanyian yang berkembang di jemaat, menjadikan musik gereja sebagai salah satu alat yang digunakan dalam pelayanan, yang juga mempunyai pengaruh besar bagi jemaat. Tidak jarang pada beberapa kesempatan, Tuhan mengizinkan sebuah nyanyian rohani bahkan musik gereja menjadi alat untuk membawa jiwa baru kepada-Nya Begitu pula dengan seorang penginjil bernama Charles Wesley, yang semasa hidupnya mampu menjadi berkat bagi setiap orang lewat lagu yang ditulisnya. Di dalam masa pelayanannya bersama saudaranya John Wesley, banyak jiwa baru yang dimenangkan bagi Tuhan. Jika John Wesley mempunyai karunia dalam berkhotbah, maka berbeda dengan adiknya Charles Wesley, di mana Tuhan mengaruniakannya talenta dalam hal bermusik, termasuk dalam membuat himne. Nyanyian himne sendiri merupakan lagu pujian yang sering dipakai dalam memuja kebesaran Tuhan, yang dinyanyikan dengan khidmat. ${ }^{5}$ Himne mempunyai kekuatan tersendiri yang kuat bagi pendengar bahkan bagi penyanyi, yang memang dipakai untuk memuji Allah. ${ }^{6}$ Dari setiap syair yang diungkapkan pada himne, mampu menggambarkan bagaimana keagungan Tuhan dan perasaan penyair tersebut. Charles Wesley sendiri telah memberikan kontribusi bagi dunia musik gerejawi dengan memberikan sekitar 9000 himne dan puisi $^{7}$ Jumlah ini terbilang fantastik bagi dunia musik.

${ }^{1}$ Khairul Ulam, "Makna Musik Gereja Terhadap Religiusitas Jemaat Umat Kristen (Studi Atas Gereja Ekklesia Kalibata Timur Jakarta Selatan)," (Skripsi, S.Ag, Universitas Islam Negeri Jakarta, 2019), 2. http://repository.uinjkt.ac.id/dspace/bitstream/123456789/45691/1/KHAIRUL\%20ULAM-FUF.pdf

${ }^{2}$ Yohana Marturia Manilani, "Bentuk Perpaduan Nyanyian Himne Dan Nyanyian Rohani Kontemporer Dalam Ibadah Di Gereja Kemah Injil Indonesia Jemaat Talitakumi Makassar” (Thesis, Sekolah Tinggi Theologia Jaffray Makassar, 2018), 1, https://repository.sttjaffray.ac.id/id/publications/269441/.

${ }^{3}$ Rohani Siahaan, "Memuji Dengan Nyanyian Dalam Ibadah Jemaat," Jurnal Jaffray 5, no. 1 (December 1, 2007): 18, https://doi.org/10.25278/jj71.v5i1.122.

${ }^{4}$ Emanuel Pranawa Dhatu Martasudjita, Musik gereja zaman sekarang (Yogyakarta: Pusat Musik Liturgi, 1998), 23.

${ }^{5}$ M. Soeharto, Kamus Musik (Jakarta: PT Gramedia Widiasarana, 1992), 52.

${ }^{6}$ Ernest Mariyanto, Kamus Liturgi Sederhana (Yogyakarta: Kanisius, 2004), 69.

${ }^{7}$ Paul Wesley Chilcote, John and Charles Wesley: Selections from Their Writings and Hymns (Woodstock: SkyLight Paths Publishing, 2011), 11. 
Charles Wesley menulis lagu dengan berbagai alasan dan tujuan, yang juga di ikuti oleh pesanan dari kakaknya. Hal ini dikarenakan Wesley bersaudara adalah rekan pelayanan yang saling mendukung satu sama lain. Ketika John Wesley ingin membawakan satu tema khotbah, maka John akan meminta adiknya untuk membuatkan lagu yang mendukung. Dan setiap lagu yang diciptakan oleh Charles Wesley ini mempunyai ceritanya masing-masing, yang berhubungan erat dengan khotbah John. Dalam pelayanan penginjilan yang Wesley bersaudara lakukan, mampu mendorong orang banyak untuk menerima Yesus sebagai Tuhan dan juruselamatnya secara pribadi serta meneguhkan iman percaya umat pada saat itu.

\section{TINJAUAN PUSTAKA}

\section{Latar Belakang Kehidupan Charles Wesley}

Charles Wesley, kelahiran Epworth, Lincolnshire di kota Inggris tanggal 18 Desember 1707. Anak bungsu dari 11 bersaudara ini lahir dari orang tua yang hidup saleh di dalam Tuhan. Ayahnya Samuel Wesley merupakan seorang pastor sekaligus musisi di sebuah gereja di Epworth yang beraliran Anglikan, sedangkan ibunya Susannah Wesley adalah seorang perempuan cantik yang mampu menguasai bahasa Yunani dan bahasa Latin. Dan tercatat sebagai seorang ibu yang dikenang sepanjang sejarah gereja Methodist ${ }^{8}$ karena keuletan dan ketekunannya mengajarkan Alkitab kepada anak-anaknya. Charles Wesley lahir dengan kondisi premature yang menyebabkan ia mudah sakit. Meskipun demikian, tetapi hal tersebut tidak menjadi alasan untuk tidak tergenapinya rencana Tuhan di dalam kehidupan Charles Wesley. Keahlian bermain musik yang dimilikinya tidak terlepas dari peran kakeknya, yaitu Samuel Sebastian Wesley, seorang pianis dan komposer musik gereja pada saat itu. ${ }^{9}$

Charles Wesley tumbuh menjadi orang yang mempunyai pengetahuan yang baik. Hal ini dikarenakan orang tuanya yaitu ibunya telah memberikan pengetahuan-pengetahuan dasar kepada anaknya, sejak kecil. Sehingga ketika dewasa, tidak sulit bagi Charles Wesley untuk melanjutkan pendidikannya di sekolah ternama. Charles Wesley sendiri pernah menyelesaikan pendidikannya di Westminster School London dan Christ Church, Oxford. Dan berbekal imu dari tempat inilah Charles Wesley memulai pelayanannya sebagai penginjil.

Dalam hidup pernikahannya dengan Sarah Gwnnye, puteri Marmaduke Gwynne, seorang hakim Welsh kaya yang bertobat ke Methodisme oleh Howell Harris, Tuhan memberikan berkat berupa delapan putera puteri, akan tetapi, sama seperti yang dialami sebelumnya oleh Charles Wesley dengan saudara-saudaranya, ia pun kehilangan anak-anaknya dan hanya menyisakan tiga orang, yaitu Charles Wesley junior putera pertama, Sarah Wesley, dan Samuel Wesley. ${ }^{10}$ Istrinya Sarah Gwnnye juga tercatat sebagai seorang wanita yang setia, ke manapun Charles Wesley pergi melayani, Sarah selalu menemaninya.

Pada tahun-tahun setelah pernikahannya, Charles Wesley dan Sarah Wesley isterinya bersama anak-anaknya, pindah ke daerah Bristol untuk memulai pelayanan. Kemudian tahun 1778, Charles Wesley meninggalkan kota Bristol dan pindah ke kota London tempat pelayanan yang baru. Sepuluh

\footnotetext{
${ }^{8}$ F.D Wellem, Riwayat Hidup Singkat Tokoh-tokoh (Jakarta: BPK Gunung Mulia, 2003), 187.

9 “The Wesley Center Online: Charles Wesley," accessed June 24, 2019, http://wesley.nnu.edu/charleswesley/.

${ }^{10}$ Ackermann et al., Encyclopedia of World History. New York: Infobase Publishing, 446.
} 
tahun setelah keluarga Charles Wesley menetap di kota London, ${ }^{11}$ pelayanannya berakhir di dunia, ia meninggal dalam usia 80 tahun pada tanggal 29 Maret 1788.

\section{Latar Belakang Kehidupan John Wesley}

John Wesley dilahirkan di Epworth tanggal 17 Juni 1703. Anak ke sepuluh dari 11 bersaudara, dan ia juga merupakan salah satu anak yang mampu bertahan hidup. John Wesley adalah kakak kandung dari Charles Wesley yang menjadi rekan sepelayanannya.

Semasa kecilnya John menempuh pendidikan di Chartehouse School di London Inggris pada tahun 1714. Setelah itu John pindah ke salah satu sekolah terbaik di Inggris, yaitu Church ChristUniversitas Oxford pada tahun 1720. Dalam kurun 4 tahun John berhasil menyelesaikan pendidikannya setingkat dengan sarjana muda, sesudah itu pada tahun berikutnya John menerima jabatan sebagai daikon (diken=calon pendeta). ${ }^{12}$ Hampir setiap tahun John mengalami peningkatan, dan saat di mana ia melanjutkan pendidikan sarjananya tahun 1726, ia juga menjabat sebagai asisten dosen di Linclon College, Oxford. Setahun berikutnya ia boleh menyelesaikan pendidikan sarjananya untuk melanjutkan tongkat estafet pelayanan dari ayahnya di kota Espworth. Selanjutnya tepat pada tahun 1729 John menjabat sebagai presbiter gereja Epworth. ${ }^{13}$

Cerita tentang kehidupan keluarga, atau tepatnya rumah tangga John Wesley tidak seindah keberhasilannya sebagai penginjil. Ia menikah dengan seorang perempuan janda bernama Mary Vazeille pada tahun 1751. Perbedaan usia di antara mereka rupanya menjadi salah satu faktor yang menimbulkan percekcokan, Mary Vazeille seorang wanita dewasa yang waktu itu John merasa tertarik karena berpikir ia akan mengurus rumah tangga dengan baik. Hal ini dikarenakan Mary sendiri sebelumnya sudah pernah menikah dengan laki-laki lain sebelum bertemu dengan John. Pada saat itu John selalu mengirimkan surat untuk Mary, yang berisi tentang betapa besarnya perasaan yang ia miliki untuk mendapatkan Mary. ${ }^{14}$ Sebagai seorang hamba Tuhan, John pasti bertemu dengan banyak orang di dalam pelayanannya, entah itu laki-laki atau perempuan. Inilah yang menjadi salah satu faktor yang menyebabkan komunikasi diantara suami dan istri ini kelihatan kurang baik. Mary sendiri sering diliputi dengan perasaan cemburu, ketika suaminya menulis surat untuk rekan wanita sepelayanannya, sehingga tidak jarang pertengkaran terjadi dalam rumah tangga mereka. John Wesley sendiri juga kelihatan seperti terlena dengan pelayanannya sehingga tidak ada lagi waktu bersama keluarga, sehingga ini juga yang membuat Mary terkadang merasa kesal. ${ }^{15}$ Pernikahan mereka ternyata tidak seindah awal mereka bertemu, pernikahan menjadi pergumulan yang berat baginya, ada yang beranggapan bahwa pernikahan mereka tidak berakhir baik.

Memang pernikahan John dan Mary tidak seindah awal mereka bertemu, bahkan ada yang beranggapan bahwa pernikahan mereka tidak berakhir baik. Namun demikian, masalah rumah tangga yang pelik tidak membuatnya putus asa dalam pelayanan, sebaliknya ia juga masih memberikan kasih sayangnya kepada istrinya, dengan tetap setia hingga Tuhan memanggil istrinya pada tahun 1781 .

${ }^{11}$ Forsaith, Peter S., Temperley, Nicholas; Banfield, Stephen, Music and the Wesleys. (Urbana: University of Illinois Press), 161-162.

${ }^{12}$ Wellem, Riwayat Hidup Singkat Tokoh-tokoh, 187.

${ }^{13}$ Wellem, 187.

${ }^{14}$ Kenneth J. Collins, John Wesley: A Theological Journey (Nashville: Abingdon Press, 2003).

${ }^{15}$ Gary L. Thomas, Sacred Marriage: Bagaimana seandainya Tuhan merancang pernikahan lebih untuk menguduskan kita daripada untuk menyenangkan kita? (Yogyakarta: Katalis Media \& Literature Yayasan Gloria, 2013), 325. 


\section{Awal Pelayanan Wesley Bersaudara}

Berbicara tentang Charles Wesley berarti berbicara juga tentang saudaranya John Wesley. Kedua saudara ini dikenal sebagai penginjil yang penuh semangat, meskipun masing-masing mereka mempunyai keahlian yang berbeda. John Wesley sang kakak adalah seorang pengkhotbah, dan Charles Weslay adiknya adalah seorang penulis nyanyian rohani, mereka berdua sangat kompak, selalu bersama dalam melaksanakan pelayanan.

Setelah menyelesaikan pendidikannya di Christ Church Oxford tahun 1727, Charles membuat suatu pelayanan yang merupakan titik awal dari seluruh pelayanannya. Bermula dari tantangan yang ditimbulkan oleh teman-temannya, yang selalu mengejek kesalehan dan ketekunan komunitas yang didirikannya. Teman-temannya sendirilah yang memberi nama untuk komunitasnya: Holy Club. Persekutuan ini didirikan oleh Charles yang bertujuan untuk membantu anggotanya memahami dengan benar tentang Alkitab, di mana setiap minggunya mereka berdiskusi mengenai Alkitab, juga memberikan pelayanan kepada sesama dengan mengunjungi orang-orang yang berada di penjara. ${ }^{16}$

Kemorosotan iman serta masalah sosial yang timbul di kalangan gereja Anglikan, gereja terbesar di daerah pelayanan Charles Wesley, ${ }^{17}$ menimbulkan ide besar untuk membuat gerakan baru. Gerakan ini bertujuan untuk melawan kelemahan-kelemahan yang menimbulkan kemerosotan, dan membuat sebuah perubahan di dalam gereja di mana ia dan saudaranya John berjemaat. Tetapi, kegigihan Wesley bersaudara untuk melayani dan membawa jiwa baru kepada Tuhan dengan semangat pantang menyerah, ditambah kemampuannya dalam menyampaikan Firman Tuhan dengan cara tersendiri, ${ }^{18}$ dan ini menjadikan mereka semakin terkenal, mengakibatkan Wesley bersaudara harus mengalami penolakan dari gereja Anglikan, yang sesungguhnya merupakan gereja yang membesarkan mereka. Lewat khotbahnya, John Wesley menolak dengan tegas, korupsi yang terjadi di pemerintahan, kekuasaan kaum kapitalis, serta birokrat yang mengeksploitasi di negaranya. ${ }^{19}$ Namun demikian, semangat melayani Tuhan tidak menjadi surut dari dua bersaudara ini ini .

Ada hal menarik bagi penulis ketika membaca perjalanan pelayanan kedua bersaudara ini. Pada tahun 1735 John dan Charles Wesley menaiki sebuah kapal dengan tujuan Georgia, Amerika. Dalam perjalanan ini, Wesley bersaudara ini bertemu dengan orang-orang Moravia, yang dikenal hidup setia di dalam Tuhan. Pertemuan dengan orang-orang Moravia ini rupanya menjadi alat di tangan Tuhan untuk meneguhkan panggilan Wesley bersaudara. Sebelumnya, John Wesley sendiri masih berada dalam keadaan bimbang dan merasakan ketidakpuasan mengenai imannya meskipun ia sudah dikenal sebagai seorang yang saleh, disiplin, dan selalu memberikan bantuan kepada orang miskin, juga setia dalam perenungan akan firman Tuhan dan berpuasa, tetapi ada kebingungan mengenai bagaimana makna keselamatannya sendiri. ${ }^{20}$

${ }^{16}$ Jan S. Aritonang, Berbagai aliran di dalam dan di sekitar gereja (Jakarta: BPK Gunung Mulia, 1995), 150.

${ }^{17}$ Ibid, 149.

${ }^{18}$ Charles Wesley and Kenneth G. C. Newport, The Sermons of Charles Wesley: A Critical Edition, with Introduction and Notes (Oxford University Press, 2001).

${ }^{19}$ Sahat Martua Lumbantobing, "Kelompok-Kelompok Kelas Sebagai Kekuatan Sosial: Sebuah Studi Kecil Terhadap Model Kelompok Kelas John Wesley Pasca Aldersgate Sebagai Bentuk Partisipasi Kristen Dalam Konteks Berteologi Kontekstual," Gema Teologi 33, no. 2: 14, http://journaltheo.ukdw.ac.id/index.php/gema/article/view/24/19

20 Sahat Martua Lumbantobing, "Kelompok-Kelompok Kelas Sebagai Kekuatan Sosial: Sebuah Studi Kecil Terhadap Model Kelompok Kelas John Wesley Pasca Aldersgate Sebagai Bentuk Partisipasi Kristen Dalam Konteks Berteologi Kontekstual," Gema Teologi 33, no. 2: 4, http://journaltheo.ukdw.ac.id/index.php/gema/article/view/24/19. 
Ketika dalam perjalanan Tuhan mengizinkan Wesley bersaudara melihat kesalehan, keteguhan, serta ketenangan yang dimiliki oleh orang-orang Moravia, meskipun badai mengguncangkan kapal mereka, tetapi orang-orang Morovia tetap bersikap tenang, bahkan mereka terus memuji Tuhan, menyembah Tuhan, sebaliknya John dan Charles tetap merasa ketakutan, ${ }^{21}$ pengalaman inilah kemudian menjadi pelajaran besar bagi Wesley bersaudara. Bahwa tidak ada alasan bagi mereka untuk takut melayani Tuhan, entah itu dalam masa sulit, masa sukar, dalam ketakutan, dalam penolakan, atau di saat apapun yang akan dihadapi, mereka belajar untuk terus taat, dan terus memberitakan kebenaran, dan kabar baik. Bahkan beberapa kali dua bersaudara ini mendapat penolakan dari jemaat-jemaat gereja, termasuk dari suku-suku Indian di daerah Georgia Amerika karena penyampaian khotbahnya yang sangat keras, hal itu tidak menyurutkan semangat melayani mereka. Sebaliknya dengan semangat yang berkobar John Wesley bersaudara tetap setia mengabarkan Injil. Ia tetap menyuarakan bahwa Allah menyelamatkan semua manusia dengan cuma-cuma, tidak ada perbedaan dalam hal pemberian keselamatan di dalam Yesus.

Dapat dikatakan, pertobatan yang sungguh dari John Wasley bersaudara semakin dikuatkan saat bertemu dengan Peter Bohler, seorang pendeta Moravia pada tanggal 24 Mei 1738 dalam pertemuan Aldergate. Saat itu, John mendengarkan pembacaan Pengantar Kitab Roma. ${ }^{22}$ Seketika itulah hatinya tersentuh, ia merasa sangat diberkati, dan semakin bersemangat lagi dalam mengemban pelayanan. John sungguh-sungguh diubahkan Tuhan, ia menyadari bahwa keselamatan sesungguhnya hanya dapat diperoleh di dalam Yesus Kristus. Selain itu, John pun merasa bahwa Tuhan telah mengampuni segala dosa-dosanya, dan membuatnya merasa layak untuk melayani Tuhan.

Terlepas dari ajaran atau teologi yang dianutnya, John dan Charles Wesley berhasil menjadi salah satu penginjil yang terkenang sepanjang masa. Charles Wesley sendiri yang dikenal dengan keahliannya menggubah dan membuat lagu serta puisi, yang digunakan saat saudaranya John melakukan KKR atau ibadah-ibadah. Lagu-lagu yang diciptakan oleh Charles Wesley sendiri banyak berbicara mengenai kekristenan, termasuk nyanyian yang bersifat injili. Nyanyian-nyanyian Charles Wesley mempunyai dasar dogmatis yang alkitabiah dengan pesan injili yang mampu dipahami dengan baik oleh orang-orang yang mengikuti ajaran Wesley bersaudara ini. ${ }^{23}$ Nyanyian yang diciptakannya senantiasa mampu menumbuhkan semangat pendengarnya untuk terus memberitakan tentang karya Kristus bagi setiap orang percaya, dan tentang bagaimana pengorbanan Yesus di atas kayu salib yang telah mati bagi orang-orang berdosa.

\section{Pengertian Penginjilan}

Kata injil berasal dari kata dalam bahasa Arab "injil" yang berarti kegirangan. Sedangkan dalam bahasa Yunani kata injil sendiri adalah "euanggelion” yang artinya kabar kegirangan. Kabar kegirangan yang dimaksudkan adalah, mengenai kabar keselamatan yang diberikan Yesus Kristus melalui pengorbanannya di atas kayu salib. ${ }^{24}$ Tegasnya, penginjilan adalah hal memberitakan injil kepada semua orang yang belum percaya, atau belum mengenal Kristus sebagai Juruselamat, juga kepada orang-orang yang tidak hidup dalam perintah Kristus. Penginjilan merupakan sebuah gerakan kekristenan yang bersifat rohani dan imani. dilakukan secara rutin, dan bertujuan untuk mengumumkan kepada orang banyak tentang karya Allah di dalam Yesus sebagai satu-satunya Tuhan dan Juruselamat manusia.

\footnotetext{
${ }^{21}$ Wellem, Riwayat Hidup Singkat Tokoh-tokoh, 187.

${ }^{22}$ Ibid., 188.

${ }^{23}$ Tony Lane, Runtut Pijar (Jakarta: BPK Gunung Mulia, 2007), 181.

${ }^{24}$ Harun Hadiwijono, Kebatinan dan Injil (Jakarta: BPK Gunung Mulia, 2009), 5.
} 
Penginjilan menjadi tugas dan tanggung jawab seorang Kristen atau warga gereja terutama dari orang-orang injili. ${ }^{25}$ Sedangkan menurut Stephen Tong, teologi penginjilan merupakan teori dasar dari memberitakan injil. Jika ingin melihat yang lebih singkat lagi, teologi adalah esensi dari memberitakan injil, sedangkan penginjilan itu sendiri adalah perluasannya, dan pemberitaan injil, semuanya harus berpusat pada Yesus Kristus. ${ }^{26}$ Tetapi juga perlu memperhatikan, bahwa berita keselamatan tidak hanya diberikan kepada orang yang tidak mengenal Kristus saja, melainkan juga kepada orang-orang Kristen yang hanya mempercayai Yesus sebatas tahu saja. Yang hanya tahu ada pengampunan, tetapi tidak menghormati pengorbanan Yesus, juga berita keselamatan. Seakan-akan kekristenan hanya dijadikan sebagai label saja, tanpa ada respon serta kesungguhan untuk hidup dalam kehendak Tuhan. Orang-orang seperti inilah, yang seharusnya juga menjadi salah satu titik fokus para pemberita Injil.

Lewat pertobatan yang dialami langsung oleh John Wesley, melahirkan sebuah paham keselamatan yang sampai saat ini menjadi pegangan jemaat dari gereja Methodis, yaitu Allah mengutus anak tunggal-Nya yaitu Yesus Kristus, untuk menebus semua umat manusia, dengan cumacuma, Allah tidak menuntut balasan dari keselamatan yang diberikan kepada manusia. Paham yang dihasilkan oleh John Wesley merupakan paham yang bertolak belakang dari paham predistinasi oleh Calvin dan George Whitefield, yang menganut paham bahwa Allah memilih dari awal manusia yang diselamatkannya. ${ }^{27}$

\section{Pengertian Nyanyian}

Sama seperti nyanyian ibadah lainnya, yang dikenal sebagai nyanyian jemaat atau community singing, nyanyian injili adalah nyanyian yang tergolong ke dalam nyanyian jemaat. Dinyanyikan secara bersama oleh seluruh umat ketika beribadah. Selain menjadi salah satu unsur liturgi, kepentingannya adalah sebagai perangkai atau penghubung dalam rumpun ibadah. ${ }^{28}$ Mengapa disebut nyanyian injili?

Menurut Rasul Paulus dalam Kolose 3:16 (band. Ef. 5:19), terdapat tiga bentuk nyanyian yang harus digunakan jemaat Kolose maupun Efesus dalam menyikapi hidup keseharian mereka sebagai umat percaya, baik secara agamawi maupun secara sosial masyarakat.

Bukan hanya di jemaat mulu-mula saja ketiga nyanyian digunakan, tetapi hingga ke gerejagereja masa kini pun, ketiga nyanyian tersebut dengan bentuk masing-masing masih tetap digunakan, bahkan dikenal sebagai ikon nyanyian gereja. ${ }^{29}$

a. Mazmur. Nyanyian pujian yang syairnya bersumber dari Alkitab. Merupakan nyanyian pujian orang Israel yang dibawakan dengan iringan berbagai ragam alat musik (Maz. 150). Ritme maupun melodi lagu, dan penulisan syairnya mengikuti sastra Ibrani. Pesan atau isi lagu mencakup seluruh aspek kehidupan umat. ${ }^{30}$

${ }^{25}$ Aritonang, Berbagai aliran di dalam dan di sekitar gereja, 227.

${ }^{26}$ Stephen Tong, Teologi Penginjilan (Surabaya: Momentum, 2012), 8-9.

${ }^{27}$ Sahat Martua Lumbantobing, "Kelompok-Kelompok Kelas Sebagai Kekuatan Sosial: Sebuah Studi Kecil Terhadap Model Kelompok Kelas John Wesley Pasca Aldersgate Sebagai Bentuk Partisipasi Kristen Dalam Konteks Berteologi Kontekstual,” Gema Teologi 33, no. 2: 5, http://journaltheo.ukdw.ac.id/index.php/gema/article/view/24/19

${ }^{28}$ Rohani Siahaan, "Memahami Nyanyian Jemaat Sebagai Sentral Musik Gereja Apa dan Bagaimana?" Jurnal Jaffray 10, no. 2 (01 Oktober 2012): 158, https://doi.org/10.25278/jj71.v10i2.57.

${ }^{29}$ Ester Elmy, Diktat Sejarah Musik Gereja (Ujung Pandang: Sekolah Tinggi Theologia Jaffray Makassar, 2016), 11-14. Belum dipublikasikan

${ }^{30}$ Elmy, 13. 
b. Kidung puji-pujian. Nyanyian yang syairnya bersumber dari Alkitab, baik dari kitab perjanjian lama maupun perjanjian baru, tetapi ada pula yang merupakan ciptaan umat sendiri. ${ }^{31}$

c. Nyanyian rohani. Dimulai dari pengalaman-pengalaman iman yang dirasakan umat Tuhan masa itu. Pesan lagu berisi nasehat-nasehat rohani yang ditujukan kepada sesama, berupa panggilan yang bersifat undangan kepada orang lain yang belum percaya. ${ }^{32}$

Melihat pembahasan yang telah diuraikan tentang bentuk nyanyian sebagaimana di atas, maka nyanyian injili merupakan nyanyian yang muncul dari adanya nyanyian rohani. Di lihat dari definisi nyanyian injili itu sendiri, yaitu sebuah nyanyian yang berbentuk bebas, bersifat emosional, sikapnya rohani dan bertujuan serta berjiwa penginjilan, maka nyanyian injili dapat dikatakan sama dengan nyanyian rohani: bersifat subjektif, memberikan kesempatan bagi orang-orang percaya untuk mengekspresikan perasaan-perasaan mereka tentang Allah serta pengalaman kerohaniaan mereka. Jika seseorang mampu menyadari bahwa sebuah nyanyian rohani yang dinyanyikan dengan kesungguhan dan hati yang tertuju kepada Allah, maka akan menciptakan persekutuan yang intim dengan-Nya. Karena nyanyian tidak hanya sebagai ungkapan syukur umat atas kebaikan Allah, melainkan juga sebagai khotbah yang disampaikan melalui nada, melodi, ritme, dan lain sebagainya. Yang mampu juga mengubah umat, dan juga sebagai kesaksian yang hidup. ${ }^{33}$ Di mana lewat nyanyian rohani, setiap pendengarnya mampu melihat bagaimana Allah berkarya dalam kehidupan umat percaya.

\section{Ciri Nyanyian Injili}

Pembahasan yang telah diuraikan di atas tentang bentuk nyanyian, maka nyanyian injili merupakan nyanyian yang muncul dari adanya nyanyian rohani. Dilihat dari definisi nyanyian injili itu sendiri, yaitu sebuah nyanyian yang berbentuk bebas, bersifat emosional, sikapnya rohani dan bertujuan serta berjiwa penginjilan, nyanyian injili sama dengan nyanyian rohani: bersifat subjektif, memberikan kesempatan bagi orang-orang percaya untuk mengekspresikan perasaan-perasaan mereka tentang Allah serta pengalaman kerohanian mereka. Ciri nyanyian injili lebih jelas lagi sebagai berikut:

Ciri pertama, memiliki dasar teologi yang benar. ${ }^{34}$ Sebagai orang percaya sangat dianjurkan untuk memilah setiap pengajaran tentang Kristus pada zaman ini. Termasuk mengenai nyanyian, sebuah nyanyian injili harus memiliki dasar alkitab yang benar.

Ciri kedua, syair atau isi dari lagu tersebut berfokus pada Yesus. ${ }^{35}$ Seperti diketahui bahwa penginjilan adalah memberitakan mengenai karya penyelamatan yang dilakukan oleh Yesus Kristus di atas kayu salib, maka dari itu di dalam nyanyian injili seharusnya terdapat makna syair yang menekankan hal ini. Sehingga lewat nyanyian orang yang belum percaya juga mampu mendengar kabar baik mengenai pengorbanan Yesus di kayu salib, bahkan mengetahui bagaimana Yesus berjuang untuk menggenapi janji Allah tentang kedatangan sang Juruselamat dunia (Yes.7:14).

${ }^{31}$ Elmy, 13.

${ }^{32}$ Elmy, 14.

${ }^{33}$ Watchman Nee and Yasperin, Seri Pembinaan Dasar: Menyanyi (Surabaya: Yayasan Perpustakaan Injil Indonesia (Yasperin), 2020).

${ }^{34}$ Albert Konaniah, Sekolah Teologi Dan Gerakan Penginjilan (Malang: Literatur SAAT Malang, 2002), 220.

${ }^{35}$ Makmur Halim, Model-Model Penginjilan Yesus: Suatu Penerapan Masa Kini (Malang: Yayasan Penerbit Gandum Mas, 2018), 25. 


\section{METODE}

Dalam tulisan ini, penulis menggunakan metodologi penelitian kualitatif, di mana metode penelitian kualitatif sendiri merupakan teknik pengumpulan data pada suatu objek permasalahan, dengan menafsirkan fenomena yang terjadi. ${ }^{36}$ Teknik ini di lakukan dengan mengumpulkan data-data melalui beberapa buku-buku, jurnal, mengakses internet dan literatur-literatur lainnya yang membahas mengenai musik gereja, nyanyian hymn atau nyanyian rohani, serta penginjilan, untuk memperoleh data yang akurat dan dapat dipertanggungjawabkan. Penulis juga melakukan studi terhadap lagu-lagu yang ditulis oleh Charles Wesley, yang terdapat di dalam buku Nyanyian Kemenangan Iman (NKI), Kidung Jemaat (KJ), dan Hymns of The Christian Life (HCL). Penulis hanya akan membahas beberapa lagu yang berhubungan dengan penginjilan saja. Penulis sendiri memilih metode penelitian kualitatif dalam karya ilmiah ini, karena metode penelitian kualitatif membantu dalam mengeksplor data-data berdasarkan makna yang ingin dikaji, serta lebih menekankan kepada kualitas daripada sebuah kuantitas dari hasil penelitian. Sehingga hasil dari penelitian berupa makna bukan generalisasi. ${ }^{37}$

\section{HASIL DAN PEMBAHASAN}

\section{Karya-Karya Charles Wesley}

Masa sekarang ini karya-karya Charles Wesley bisa dikatakan dikenal dalam semua denominasi gereja yang ada dan hampir semua karya-karyanya tercantum di dalam beberapa buku nyanyian. Di bawah ini adalah daftar karya Charles Wesley yang terdapat dalam 3 buku nyanyian yang sudah dikenal, yaitu: buku Nyanyian Kemenangan Iman (NKI), Hymns of The Christian Life (HCL), dan Kidung Jemaat (KJ).

Tabel 1. Daftar Karya Charles Wesley Yang Terdapat dalam 3 buku nyanyian, yaitu: Nyanyian Kemenangan Iman, Hymns of The Christian Life (HCL), dan Kidung Jemaat

\begin{tabular}{|l|c|r|r|r|}
\hline \multirow{2}{*}{ NO } & JUDUL LAGU & \multicolumn{2}{|c|}{ SUMBER BUKU } \\
\cline { 3 - 5 } & NKI & HCL & KJ \\
\hline 1. & Marilah, Raja Yang Berkuasa & 3 & & \\
\hline & Come, Thou Almighty King & & 3 & \\
\hline & Ya Khalik Semesta & & & \\
\hline 2. & Tuhan Hati Yang Suci & 10 & & \\
\hline & O For a Heart to Praise My God & & & \\
\hline 3. & Bangkit, Hai Nyawaku & 15 & & \\
\hline & Arise, My Soul, Arise! & & 111 & \\
\hline 4. & Walau Seribu Lidahku & 17 & & \\
\hline
\end{tabular}

${ }^{36}$ Albi Anggito, Johan Setiawan, Metodologi penelitian kualitatif (Sukabumi, Jawa Barat: CV Jejak, 2018), 8.

${ }^{37}$ Umrati and Hengki Wijaya, Analisis Data Kualitatif Teori Konsep dalam Penelitian Pendidikan (Sekolah Tinggi Theologia Jaffray, 2020), 8-11. 


\begin{tabular}{|c|c|c|c|c|}
\hline & O For a Thousand Tongues & & 3 & \\
\hline & Beribu Lidah Patutlah & & & 294 \\
\hline \multirow[t]{3}{*}{5.} & Dengarlah Malaikat Nyanyi & 43 & & \\
\hline & Hark, the Herald Angels Sing & & 45 & \\
\hline & Gita Sorga Bergema & & & 99 \\
\hline \multirow[t]{3}{*}{6.} & $\begin{array}{c}\text { Hari Inilah Yesus Sudah Bangkit, } \\
\text { Haleluya }\end{array}$ & 52 & & \\
\hline & Christ the Lord Is Risen Today & & 84 & \\
\hline & Kristus Bangkit! Soraklah & & & 188 \\
\hline \multirow[t]{2}{*}{7.} & Ku Tahu Penebusku Hidup & 60 & & \\
\hline & I Know That My Redeemer Lives & & 95 & \\
\hline \multirow[t]{2}{*}{8.} & Rahmat Sangat & 76 & & \\
\hline & Depth of Mercy! Can There Be & & 143 & \\
\hline \multirow[t]{2}{*}{9.} & Maju, Hai Pahlawan & 113 & & \\
\hline & Soldiers of Christ, Arise & & 427 & \\
\hline \multirow[t]{2}{*}{10.} & Ku Ada Tugas Hendak Ditunaikan & 133 & & \\
\hline & A Charge to keep I Have & & 350 & \\
\hline \multirow[t]{3}{*}{11.} & Yesus Tempat Berlindung & 153 & & \\
\hline & Jesus, Lover of My Soul & & 273 & \\
\hline & Angin Ribut Menyerang & & & 30 \\
\hline \multirow[t]{3}{*}{12.} & Kasih Ilahi dari Surga & 218 & & \\
\hline & Love Divine, All Loves & & 180 & \\
\hline & Mahakasih Yang Ilahi & & & 58 \\
\hline \multirow[t]{2}{*}{13.} & Disini Aku Mau Tinggal & 251 & & \\
\hline & Forever Here My Rest Shall Be & & 287 & \\
\hline 14. & Kusembah Pada Pengasihan Almasih & 270 & & \\
\hline 15. & Mungkinkah? & 291 & & \\
\hline
\end{tabular}




\begin{tabular}{|c|c|c|c|c|} 
& And Can It Be That I Should Gain & & 94 & \\
\hline & Mungkinkah Aku pun Serta & & & 31 \\
\hline 16 & Rejoice, the Lord Is King & & 103 & \\
\hline & Masyhurkan Rajamu & & & 224 \\
\hline
\end{tabular}

\section{Nyanyian-Nyanyian Yang Lahir Dari Pelayanan}

Charles Wesley diketahui sebagai penulis lagu terbaik di daratan Inggris pada masa itu. Setiap karyanya menempati posisi yang terbaik di hati para pendengarnya, termasuk jemaat gereja yang dilayani. Seperti yang sudah dibahas sebelumnya, nyanyian-nyanyian yang diciptakannya itu digunakan untuk membantu pelayanan kakaknya yaitu John Wesley.

Bagaimana kedua bersaudara ini bekerjasama dalam melakukan pelayanan hanya untuk kemuliaan Tuhan tergambar melalui syair dan lagu yang dihasilkan pada masa pelayanan, meski pada perkembangan berikutnya, nyanyian-nyanian karya Charles ini banyak yang digubah oleh musisimusisi yang berbeda, artinya lagu atau melodi baru, tetapi syair lagu tetap adalah miliknya, maka nyanyian-nyanyian yang ditempatkan secara seksama dan diletakkan pada rumpun ibadah yang tepat, akan sangat jelas terlihat karya kedua bersaudara ini mencakup semua aspek kehidupan umat yang terfokus kepada Kristus dan karya keselamatan-Nya.

Nyanyian-nyanyian yang dihasilkan Charles Wesley bersama saudaranya John selama pelayanan yang berkaitan dengan penginjilan dapat dicatat berikut sinopsisnya:

\section{"Dengarlah Malaikat Nyanyi”}

Nyanyian ini ditulis pertama kali oleh Charles Wesley pada tahun 1739. Lagu ini adalah lagu natal pertama bagi Charles, yang diaransemen oleh F. Mendelssohn yang merupakan composer lagu berjenis cantata. Banyak lagu yang ditulis oleh Mendelssohn yang disukai oleh jemaat, kolaborasi antara dua musisi ini menjadikan lagu dengan judul asli Hark the Angels Sing menjadi sangat terkenal. Lagu ini tidak asing lagi bagi orang Kristen, karena lagu ini merupakan lagu yang selalu dikumandangkan ketika hari natal tiba. Nyanyian ini mengajak jemaat Tuhan untuk bersukacita, karena anak Allah telah lahir kedunia. Anak Allah yang memberi diri untuk menjadi manusia dan menyelamatkan manusia yang berdosa. Ia meninggalkan tahta-Nya di surga, dan datang ke dunia dalam wujud manusia. Maka lewat lagu ini, Charles Wesley mengajak jemaat Tuhan, untuk bersukacita dan memuji Tuhan. Nyanyian ini selalu dinyanyikan biasanya pada perayaan natal.

\section{“Rahmat Sangat”}

Lagu ini muncul pertama kali pada tahun 1740. Lewat lagu ini Charles mencoba untuk menjelaskan sosok Kristus yang menawan, yang menderita disiksa, dihina, dan dicaci maki, tetapi meskipun dalam keadaan kesakitan-Nya Yesus masih mengasihi dengan kasih yang tak terbatas kepada orang-orang yang telah melukai-Nya. ${ }^{38}$ Charles Wesley juga menggambarkan bagaimana keadaan manusia yang menyadari dan meminta pertolongan dari Tuhan. Charles Wesley menyadari bahwa sebagai manusia berdosa, manusia tidak dapat berbuat apa-apa tanpa rahmat Allah, untuk sebab itu lagu ini merupakan lagu pengampunan dosa.

${ }^{38}$ Kenneth W. Osbeck, 101 More Hymn Stories (USA: Kregel Publications, 1985), 74. 


\section{"Maju, Hai Pahlawan"}

Soldiers of Christ arise merupakan sebuah lagu yang awalnya merupakan sebuah puisi lama, yang terdiri dari 16 belas ayat, yang ditulis pada tahun 1742 .

Nyanyian Charles Wesley ini di tulis berdasarkan nats firman Tuhan dari Efesus 6:10-20, yang berbicara mengenai perlengkapan persenjataan rohani. Rasul Paulus mengingatkan kepada para pengikut Kristus yang adalah prajurit-prajurit kebenaran untuk berperang melawan kuasa kegelapan. Prajurit Kristus harus selalu berjaga-jaga, memakai perlengkapan Kristus yaitu, ikat pinggang kebenaran, berbaju zirahkan keadilan, berkasutkan kerelaan, perisai iman, ketopong keselamatan, dan pedang Roh. Karena, peperangan rohani kapan saja bisa terjadi, tetapi dibalik itu semua setiap peperangan adalah milik Allah yang adalah sumber kekuatan. Selain itu perlengkapan senjata rohani yang dimaksudkan oleh Paulus dalam teks ini adalah, menjelaskan mengenai makna bahwa manusia tidak dapat berbuat apa-apa tanpa Tuhan, kekuatan yang diberikan oleh Allah melalui pengorbanan dan kematian sang Kristus merupakan alasan terkuat bagi seseorang untuk harus bertahan dalam tipu muslihat iblis. ${ }^{39}$ Perjuangan yang harus dilalui oleh umat percaya adalah perjuangan yang tidak mudah, karena harus melawan kuasa Iblis, yang secara manusiawi tidak akan mungkin bisa melawannya, kecuali dengan kekuatan Allah. ${ }^{40}$

Hal inilah yang mendasari Charles Wesley untuk menulis lagu ini, ia ingin ketika orang Kristen mengetahui bahwa dirinya adalah seorang prajurit Kristus, maka seharusnya orang Kristen mampu untuk siap sedia mengalami peperangan rohani, dengan memakai segala persenjataan yang sudah Allah siapkan. Perjuangan manusia dalam memberitakan kabar baik, adalah sesuatu hal yang tidak mudah. Tidak hanya berhadapan dengan orang-orang yang menolak injil, ataupun yang tidak hidup dalam kabar baik itu, tetapi juga melawan tipu muslihat iblis dalam membutakan melihat kebenaran injil itu sendiri untuk dimengerti oleh orang-orang tersebut. Itulah mengapa Charles Wesley lewat lagunya selain memberitahukan bahwa seorang Kristen adalah prajurit Kristus yang harus siap sedia dengan persenjataan rohaninya. Ia juga menginginkan bahwa orang percaya dengan kesadaran penuh menyadari bahwa kekuatannya dalam mempertahankan iman itu berasal dari Allah, bukan karena kuat gagah manusia.

\section{"Ku Ada Tugas Hendak Ditunaikan"}

Charles Wesley ketika menuliskan lagu ini terinsipirasi dari tulisan Matthew Henry tentang kitab Imamat 8:35 yang mengatakan bahwa setiap orang percaya memiliki kewajiban untuk memelihara kehidupan rohani, untuk menjadi alat tangan Tuhan dalam membawa jiwa baru. Dalam pelayanan yang dilakukan oleh Wesley bersaudara seringkali mereka mendapati penganiayaan dalam pelayanan, yang dilakukan oleh pendeta-pendeta Anglikan. Tetapi Wesley tetap semangat untuk menjalankan tugas pelayanan yang dilakukan. Nyanyian inilah yang menjadi kekuatan bagi orangorang Methodis saat itu, Wesley bersaudara bersama dengan rekan-rekannya mengatakan bahwa mereka tidak akan merasa takut ketika menghadapi kematian di dalam pelayanan karena bagi Wesley bersaudara hidup dan mati adalah kehendak $\operatorname{Tuhan}^{41}$, kalaupun mereka harus mati dalam pelayanan mereka menyakini bahwa kehidupan kekal telah diterimanya dengan semangat penginjilan yang dimilikinya, dalam lagu ini menuliskan tentang bagaimana Charles meminta hikmat dan kekuatan kepada Tuhan dalam mengemban tugas pelayanannya, untuk membawa jiwa baru. Charles Wesley

\footnotetext{
39 J. L. Ch. Abineno, Taf. Alk. Surat Efesus (Jakarta: BPK Gunung Mulia, 2003), 237.

${ }^{40}$ Abineno, 240.

${ }^{41}$ Osbeck, 101 More Hymn Stories, 14-15.
} 
menyadari bahwa ada banyak tantangan yang akan dihadapi olehnya, untuk sebab itu Charles meminta pertolongan kepada Tuhan untuk dapat menjalankan tugas pelayanannya.

\section{“Mungkinkah?”}

Nyanyian ini ditulis pada tahun 1738 yang merupakan isi hati dari Charles yang pada saat itu merasakan kedamaian yang Tuhan berikan, ketika ia boleh mengalami pertobatan yang sesungguhnya. ${ }^{42}$ Meskipun pada awalnya ia merasa ragu dengan keselamatannya, Charles merasa sebagai orang yang berdosa, dan sebagai orang yang cemar, tetapi disaat yang sama Charles melihat bagaimana Yesus mati diatas kayu salib mencurahkan darah-Nya untuk menyelamatkan hidupnya dari dosa, meninggalkan tahta kudusnya untuk menjadi penyelamat bagi manusia. Dan pada akhirnya Charles mengetahui bahwa semua yang Yesus lakukan untuk manusia, didasari oleh kasih yang tulus. Kasih yang datang-Nya dari Bapa, yang ingin menyelamatkan semua orang yang berdosa.

\section{RELEVANSI LAGU HYMN DALAM PELAYANAN WESLEY BERSAUDARA}

Nyanyian menyatukan jemaat. Nyanyian adalah partisipasi langsung jemaat dalam sebuah ibadah. Artinya, nyanyian mutlak dalam ibadah karena perannya adalah mendukung umat mengikuti seluruh rangkaian ibadah. Tetapi, bagaimana nyanyian bisa menjadi nyanyian yang begitu disukai dan digemari oleh umat atau jemaat gereja, tentu masing -masing memiliki kisah tersendiri. Tidak terkecuali seorang penginjil Charles Wesley. Meskipun pada awalnya ia menciptakan lagu-lagunya untuk mendukung pelayanan saudaranya John Wesley, namun pada akhirnya lagu-lagu tersebut bisa menjadi sangat terkenal di seantero jagad dan bahkan masih dinyanyikan gereja-gereja masa sekarang.

Charles Wesley memiliki banyak nyanyian yang penciptaannya berlatar belakang suasana medan pelayanannya, dan juga sesuai dengan tema ibadah yang akan dilaksanakan. Seperti lagu yang penulis pilih sebagai contoh, yaitu: "Mungkinkah?".

Lagu yang berjudul bahasa Indonesia: “Mungkinkah?" terdapat dalam buku nyanyian kemenangan iman \{NKI 291), sedangkan dalam buku nyanyian Hymns of Christian Life, judul aslinya dalam bahasa Inggris adalah, And Can It Be That I Should Gain penulis hendak mengetahui latar belakang lagu, makna syairnya, makna teologisnya, dan bagaimana peran lagu ini dalam pelayanan Wesley bersaudara.

\section{Latar Belakang Lagu And Can It Be That I Should Gain}

And Can It Be That I Should Gain sebuah karya Charles Wesley yang cukup dikenal di kalangan gereja-gereja injili pada umumnya. Nyanyian yang ditulis tepatnya pada 20 Mei 1738, saat ia mengalami kedamaian setelah merasakan pertobatan yang sesungguhnya. ${ }^{43}$ Lagu ini menjadi jawaban dari pertanyaan yang selama ini ditanyakan oleh Wesley bersaudara mengenai keselamatan mereka. Di satu malam saat ia menuliskan lagu ini, Charles merasakan kemenangan dari segala dosa, dan juga memiliki keyakinan yang kuat bahwa ia akan berjalan ke depan dengan keberanian yang datangnya dari Allah. Perasaan sukacita yang dirasakan merupakan gambaran betapa baiknya Allah bagi Wesley bersaudara, di mana atas rencana penebusan yang dilakukan oleh anak Allah yang hidup ${ }^{44}$ menjadikan mereka sebagai orang-orang yang tetap semangat dalam pelayanan mereka.

${ }^{42}$ Robert Morgan, Then Sings My Soul Special Edition (Thomas Nelson, 2010), 45.

${ }^{43}$ Morgan, 45.

${ }^{44}$ Kenneth W. Osbeck, Amazing Grace: 366 Inspiring Hymn Stories for Daily Devotions (USA: Kregel Publications, 2002), 50. 
Seperti di awal tulisan sudah disampaikan, bahwa Wesley bersaudara lahir dari keluarga yang taat akan firman Tuhan, mereka adalah putera seorang pendeta, tetapi ternyata itu semua tidak menjamin Wesley bersaudara mampu merasakan sukacita dalam kehidupan rohani. Justru pertemuan Wesley bersaudara dengan orang-orang Moravialah yang menjadi titik balik kehidupan rohani mereka.

Dalam pelayanan yang dilakukan oleh Wesley bersaudara, mereka harus menempuh jarak yang sangat jauh untuk menyampaikan kabar baik, dengan menunggangi kuda, semua rasa lelah yang dirasakan oleh Wesley bersaudara terbayarkan ketika melihat orang banyak berkumpul untuk mendengarkan khotbah John Wesley, serta menyanyikan lagu-lagu ciptaan Charles Wesley bersamasama. Dari pengalaman ini, Charles mengetahui bahwa semua yang Yesus lakukan untuk manusia, didasari oleh kasih yang tulus. Kasih yang datang-Nya dari Bapa, yang ingin menyelamatkan semua orang yang berdosa. Lagu ini sendiri digunakan oleh John Wesley dalam mendukung khotbahnya pada tahun 1738 , ketika ia berbicara mengenai keselamatan oleh iman. ${ }^{45}$

\section{Makna Syair “Mungkinkah?”}

Dalam sebuah nyanyian, syair adalah salah satu unsur yang paling penting, tanpa syair seorang penyanyi akan merasa sulit mengetahui maksud dari sebuah lagu, dan pastinya akan merasa susah untuk menginterpretasikan lagu. Oleh sebab itu penulis akan menjelaskan maksud dari masingmasing bait lagu ini, berdasarkan terjemahan dari buku Nyanyian Kemenangan Iman.

1. Mungkinkah aku pun serta tertolong oleh darah-Nya ?

Karena ku Yesus disiksa yang menyebabkan kematian-Nya.

Agung benar ya Tuhanku, Engkau tersiksa gantiku

Reff : Agung Benar ya Tuhanku, Engkau tersiksa gantiku

Ya Tuhanku, Engkau tersiksa gantiku.

2. Para malaikat sekalipun tiada dapat berperi

Apa sebab yang abadi menanggung siksa yang keji

Kasih-Nyalah alasan-Nya menanggung dosa dunia - Reff .

3. Ditinggalkan-Nya tahta-Nya menuju dunia yang cemar

Ditinggalkan-Nya kuasa-Nya, di dorong kasih yang benar

Dan aku pun tertolonglah, terpilihlah jadi milik-Nya - Reff.

Pada bait pertama menceritakan tentang bagaimana Charles memberikan pengagungan kepada Yesus atas karya penyelamatan yang dilakukan-Nya bagi umat manusia. Charles menggambarkan pribadi Kristus bukan sebagai hakim tetapi sebagai sahabat orang berdosa. ${ }^{46}$

Pada bait kedua, Charles seakan memberikan pernyataan bahwa malaikat saja tidak mengetahui rancangan Allah ini, rencana penyelamatan yang disiapkan-Nya. Tidak ada satu pun ciptaan yang mengetahui mengapa Allah rela mengorbankan anak-Nya yang tunggal untuk menebus dosa manusia. Hanya saja pada refrain lagu ini Charles mencoba untuk menjawab pertanyaan itu, dengan satu kalimat yaitu hanya karena kasih-Nya bagi dunia, karena kebaikan-Nya bagi umat manusia, dan karena janji Allah, sehingga Allah mengorbankan anak-Nya yang tunggal untuk menyatakan kasih-Nya itu. Ada pengagungan yang diberikan, lewat karya penebusan.

Pada bait ketiga, menyampaikan kepada orang percaya tentang bagaimana Yesus yang adalah anak Allah satu-satunya, yang dengan keagungan-Nya di surga, dan dengan kerajaan-Nya, rela

${ }^{45}$ James Leslie Houlden, Jesus in History, Thought, and Culture: An Encyclopedia (California: ABCCLIO, 2003), 876.

${ }^{46}$ Houlden, 876. 
meninggalkan tahta kudus-Nya untuk datang ke dunia yang fana, bahkan meninggalkan kekuasaanNya untuk menyelamatkan manusia yang berdosa.

Dari ketiga bait lagu And Can It Be That I Should Gain memberikan pemahaman bahwa Wesley bersaudara diselamatkan bukan karena semua pelayanan yang dilakukannya, atau kebaikannya dilakukan, tetapi karena iman. Iman yang menyelamatkan mereka dari semua perasaan takut, perasaan tidak layak, dan lain sebagainya. Iman yang dimiliki oleh Wesley bersaudara yang memungkinkan mereka untuk menerima kehidupan kekal, lewat pengorbanan Yesus diatas kayu salib.

\section{Makna Teologis “Mungkinkah?”}

Seperti yang telah diuraikan oleh penulis sebelumnya, mengenai latar belakang lagu, penulis mendapati satu fakta menarik bahwa setiap lagu yang ditulis Charles Wesley senantiasa melihat kepada nas Alkitab, artinya bahwa lagu-lagu Charles Wesley mempunyai kesinambungan dengan setiap khotbah yang disampaikan oleh John Wesley saudaranya. Begitu pun lagu "Mungkinkah?" merupakan nyanyian yang ditulisnya berdasarkan Wahyu 1:5

Kitab Wahyu sendiri diketahui sebagai kitab terakhir di dalam urutan kitab yang ada. Secara garis besar kitab ini berbicara mengenai nubuatan kedatangan Yesus Kristus untuk kedua kalinya ke dunia. ${ }^{47}$ Pasal pertama dari ayat ini berbicara mengenai beberapa bagian, termasuk di dalamnya mengenai salam kepada ketujuh jemaat yang berada di Asia Kecil. Salam yang diberikan oleh Yohanes kepada ketujuh jemaat ini, merupakan salam semangat dan penguatan. Pada ayatnya yang kelima bagian kedua, Yohanes memberikan pujian dan hormat kepada Sang Juruselamat yang dengan darah-Nya yang kudus melepaskan manusia dari belenggu dosa. ${ }^{48}$ Inilah yang menjadi landasan ayat yang dikutip oleh Charles Wesley dalam penulisan lagu And Can It Be That I Should Gain.

Ayatnya yang kelima dikatakan juga sebagai bagian dari doksologi, di mana doksologi merupakan ungkapan pujian kepada Allah. ${ }^{49}$ Penjelasan tentang kalimat "yang mengasihi kita" menunjukan bahwa kasih yang Allah berikan adalah kasih yang bersifat kekal, dan telah nyata melalui pengorbanan-Nya di atas kayu salib. Dengan pengorbanan Yesus melepaskan manusia dari dosa, untuk sekali dan selamanya. ${ }^{50}$

Inilah gambaran dari ayat yang dikutip oleh Charles dalam penulisan lagu "Mungkinkah?". Lagu yang juga sangat digemari oleh Wesley bersaudara, karena setiap syair yang ditulisnya adalah cerita mengenai pertobatannya. Pertobatan yang dimaksudkan bukan dari kehidupan lama yang melakukan hal-hal jahat, tetapi bertobat dari ketidakyakinan dalam dirinya untuk menjadi bagian dalam kerajaan surga. Ketika Wesley bersaudara menyakini dengan sungguh-sungguh imannya, maka mereka tahu bahwa kehidupan kekal yang telah disiapkan Tuhan mampu untuk memberikan kekuatan bagi dirinya untuk terus semangat dalam pelayanan. Salah satu bukti dari iman Wesley adalah, menjadi berkat bagi orang lain. Wesley tahu betul bahwa Allah yang Ia layani adalah Allah yang hidup, yang menginginkan kabar baik, serta pertobatan juga dialami oleh orang banyak. Nyanyian rohani yang diciptakan oleh Charles Wesley, menjadi pendukung dalam pelayanan seorang John Wesley. Mereka adalah pelayan Tuhan, yang mempunyai hati kepada jiwa-jiwa yang tersesat. John Wesley menyadari, bahwa meskipun Ia telah lahir dan dibesarkan dalam lingkungan Kristen yang takut Tuhan, itu tidak menjamin bahwa dirinya benar-benar menghidupi Injil Kristus, melainkan

${ }^{47}$ Donald Guthrie, Teologi Perjanjian Baru 3 (Jakarta: BPK Gunung Mulia, 2009), 156.

${ }^{48}$ Eka Darmaputera, Menyingkap Janji Tuhan: Pemahaman Kitab Wahyu Tentang Iman Dan

Pengharapan di Tengah Penganiayaan Dan Penderita (Jakarta: BPK Gunung Mulia, 2012), 35.

${ }^{49}$ Frans Sugiyono, Mencintai Liturgi (Kanisius, 2010), 96.

${ }^{50}$ Simon J. Kistemaker, Tafsiran Kitab Wahyu (Surabaya: Momentum, 2014), 89. 
pertobatan yang didasari dengan kesadaran penuh akan kebaikan Allah bagi manusia, serta mampu menghasilkan buah dalam perjalanan iman adalah seorang yang mampu dikatakan sebagai murid Kristus yang sejati. ${ }^{51}$

Di masa sekarang ini, di mana dunia diperhadapkan dengan situasi pandemi Covid-19 yang semakin mengganas, menyebabkan banyak permasalahan yang tidak terduga sebelumnya. Pandemi Covid-19 yang telah merenggut jutaan warga dunia, meninggalkan kesedihan yang sangat mendalam. Selain itu, hampir semua sektor dalam pemerintahan harus mengalami gangguan. Perekonomian, pendidikan, pariwisata, kesehatan, dan lain sebagainya, harus merasakan ketidaknyamanan ini. Banyak orang yang kehilangan lapangan pekerjaan, menurunnya omset penjualan, juga menurunnya jumlah wisatawan, membuat dampak covid-19 menjadi sangat meresahkan. Di tengah-tengah keresahan manusia saat ini, covid-19 tidak hanya menyerang kesehatan jasmani saja, melainkan juga menyerang kesehatan mental seseorang, oleh karena itu tidak jarang kita menemui seseorang yang mengalami stres, keputusasaan, ketakutan, depresi, dan lain sebagainya. ${ }^{52}$

Dampak negatif yang sangat dirasakan oleh seluruh warga dunia, menyebabkan ketidak mampuan dalam berpikir rasional lagi. Tidak heran jika banyak umat Tuhan yang mulai mengalami suam-suam kuku. Sejak bulan maret tahun 2020, ada banyak gereja yang harus merumahkan jemaatnya. Harus memulai kebiasaan baru dengan beribadah di rumah masing-masing. Ini adalah sebuah hal yang baru bagi kekristenan, tetapi sebenarnya tidak mengurangi makna dari ibadah itu sendiri. Entah ibadah di rumah, ataupun di gereja, jika dimaknai dengan benar maka juga akan menjadi persembahan yang harum baru bagi nama Tuhan. Seharusnnya umat kristiani mampu untuk selalu bersyukur untuk setiap hal yang Tuhan izinkan terjadi termasuk pandemi covid-19 ini.

Gereja mempunyai tugas yang besar untuk mampu terus menjalankan amanat agung di tengahtengah ketidak pastian kapan berhentinya pandemi covid-19 ini. Nyanyian penginjilan yang dikarang oleh Charles Wesley, juga menjadi kekuatan bagi umat percaya. Ada pengharapan, juga semangat dalam mempertahankan iman percaya kepada Yesus Kristus, serta adanya senjata rohani yang Tuhan berikan bagi setiap umat-Nya, untuk menjadi pegangan dalam menjalani masa-masa sulit, bahwa Allah selalu menyertai dan melindungi.

\section{KESIMPULAN}

Berdasarkan uraian yang telah dijabarkan sebelumnya, maka penulis memberikan kesimpulan tentang lagu hymn karya Charles Wesley dan relevansinya bagi penginjilan Wesley Bersaudara, bahwa setiap lagu hymn yang di tulis oleh Charles Wesley merupakan sebuah nyanyian rohani yang menjadi salah satu alat pendukung khotbah dari saudaranya, yaitu John Wesley, termasuk nyanyiannyanyian penginjilan. Setiap lagu atau nyanyian yang di tulis oleh Charles Wesley merupakan sebuah khotbah yang disampaikan lewat nada, ritme, dan syair. Kedatangan Yesus ke dalam dunia, merupakan sebuah karya penyelamatan yang sejak zaman Perjanjian Lama telah dirancangkan (Lukas 2). Menurut Paulus sendiri, Yesus diutus oleh Allah, tidak hanya membebaskan manusia dari dosa, tetapi Yesus juga menjadi jembatan bagi orang-orang kaya dan miskin, atau orang-orang yang

${ }^{51}$ Einar Martahan Sitompul, Teologi politik: agama-agama dan kekuasaan (Jakarta: Badan Penelitian dan Pengembangan, Persekutuan Gereja-Gereja di Indonesia, 2004), 164.

52 Agus Riyadi dkk., Dinamika Pendekatan Dalam Penangananan Covid-19 (Pekalongan, Jawa Tengah: Penerbit NEM, 2020), 135. 
bersukacita maupun berdukacita, orang-orang yang mempunyai jabatan dan yang tidak mempunyai jabatan..$^{53}$

Pertobatan yang dialami oleh John Wesley, merupakan titik awal mulanya semangat penginjilan yang dimilikinya. ${ }^{54}$ Wesley bersaudara hadir dalam pelayanannya, untuk menyuarakan bahwa kedudukan manusia sama di mata Allah. Allah mengutus anak tunggalnya untuk menebus semua manusia dari dosa, serta menawarkan keselamatan secara cuma-cuma kepada semua orang. Injil tidak hanya diberikan bagi orang kaya saja, atau hanya bagi orang yang mempunyai kedudukan saja, melainkan mereka yang dianggap hina oleh dunia, merekalah yang dipilih Allah (1 Korintus1:27). Lewat Nyanyian penginjilan karya Charles Wesley, menggambarkan karya penyelamatan yang Allah lakukan melalui pengorban-Nya di atas kayu salib, dan hal ini berhubungan dengan setiap khotbahkhotbah dari John Wesley mengenai iman dan karya penyelamatan yang Yesus lakukan. Dan juga lagu karya Charles Wesley juga menekankan bagaimana umat percaya pada saat itu, tidak hanya memakai label kristen saja dalam kesehariannya, tetapi lebih kepada bagaimana umat percaya mampu hidup dalam pertobatan yang sesungguhnya, memaknai Injil dengan baik, melakukan firman Tuhan, serta menghasilkan buah-buah rohani. Sehingga lewat nyanyian, iman jemaat dapat diteguhkan dan makin percaya bahwa Yesuslah satu-satunya jalan keselamatan. Karena pada saat itu umat kristen hanya sebatas mengetahui Yesus Kristus saja, tetapi tidak menghidupi Kristus itu sendiri.

${ }^{53}$ Eka Darmaputera, Tatkala Allah Melawat Umatnya (Jakarta: BPK Gunung Mulia, 2008), 97.

54 Sahat Martua Lumbantobing, "Kelompok-Kelompok Kelas Sebagai Kekuatan Sosial: Sebuah Studi Kecil Terhadap Model Kelompok Kelas John Wesley Pasca Aldersgate Sebagai Bentuk Partisipasi Kristen Dalam Konteks Berteologi Kontekstual," Gema Teologi 33, no. 2: 5, http://journaltheo.ukdw.ac.id/index.php/gema/article/view/24/19 


\section{DAFTAR PUSTAKA}

Abineno, J. L. Ch. Tafsiran Alkitab Surat Efesus. Jakarta: BPK Gunung Mulia, 2003.

Ackermann, Marsha E., Michael J. Schroeder, Janice J. Terry, Jiu-Hwa Lo Upshur, Mark F. Whitters. Encyclopedia of World History. New York: Infobase Publishing, 2008.

Anggito, A., Johan Setiawan. Metodologi penelitian kualitatif. Sukabumi, Jawa Barat: CV Jejak, 2018. Aritonang, Jan S. Berbagai aliran di dalam dan di sekitar gereja. Jakarta: BPK Gunung Mulia, 1995.

Chilcote, Paul Wesley. John and Charles Wesley: Selections from Their Writings and Hymns.

Woodstock: SkyLight Paths Publishing, 2011.

Collins, Kenneth J. John Wesley: A Theological Journey. Nashville: Abingdon Press, 2003.

Darmaputera, Eka. Menyingkap Janji Tuhan: Pemahaman Kitab Wahyu Tentang Iman Dan Pengharapan di Tengah Penganiayaan Dan Penderita. Jakarta: BPK Gunung Mulia, 2012. . Tatkala Allah Melawat Umatnya. Jakarta: BPK Gunung Mulia, 2008.

Elmy, Ester. Diktat Sejarah Musik Gereja. Ujung Pandang: Sekolah Tinggi Theologia Jaffray Makassar, 2016.

Guthrie, Donald. Teologi Perjanjian Baru 3. Jakarta: BPK Gunung Mulia, 2009.

Hadiwijono, Harun. Kebatinan dan Injil. BPK Gunung Mulia, 2009.

Halim, Makmur. Model-Model Penginjilan Yesus: Suatu Penerapan Masa Kini. Malang: Yayasan Penerbit Gandum Mas, 2018.

Houlden, James Leslie. Jesus in History, Thought, and Culture: An Encyclopedia. California: ABCCLIO, 2003.

Kistemaker, Simon J. Tafsiran Kitab Wahyu. Surabaya: Momentum, 2014.

Konaniah, Albert. Sekolah Teologi Dan Gerakan Penginjilan. Malang: Literatur SAAT Malang, 2002. Lane, Tony. Runtut Pijar. Jakarta: BPK Gunung Mulia, 2007.

Lumbantobing, Sahat M. "Kelompok-Kelompok Kelas Sebagai Kekuatan Sosial: Sebuah Studi Kecil Terhadap Model Kelompok Kelas John Wesley Pasca Aldersgate Sebagai Bentuk Partisipasi Kristen Dalam Konteks Berteologi Kontekstual." Gema Teologi 33, no. 2: 1-19. http://journaltheo.ukdw.ac.id/index.php/gema/article/view/24/19

Manilani, Yohana Marturia. "Bentuk Perpaduan Nyanyian Himne Dan Nyanyian Rohani Kontemporer Dalam Ibadah Di Gereja Kemah Injil Indonesia Jemaat Talitakumi Makassar.” Thesis, Sekolah Tinggi Theologia Jaffray Makassar, 2018. https://repository.sttjaffray.ac.id/id/publications/269441/.

Mariyanto, Ernest. Kamus Liturgi Sederhana. Kanisius, 2004.

Martasudjita, Emanuel Pranawa Dhatu. Musik gereja zaman sekarang. Yogyakarta: Pusat Musik Liturgi, 1998.

Morgan, Robert. Then Sings My Soul Special Edition. Thomas Nelson, 2010.

Nee, Watchman, and Yasperin. Seri Pembinaan Dasar: Menyanyi. Surabaya: Yayasan Perpustakaan Injil Indonesia (Yasperin), 2020.

Osbeck, Kenneth W. 101 More Hymn Stories. USA: Kregel Publications, 1985. Amazing Grace: 366 Inspiring Hymn Stories for Daily Devotions. USA: Kregel Publications, 2002.

Riyadi, A. dkk. Dinamika Pendekatan Dalam Penangananan Covid-19. Pekalongan, Jawa Tengah: Penerbit NEM, 2020.

Siahaan, Rohani. "Memahami Nyanyian Jemaat Sebagai Sentral Musik Gereja Apa dan Bagaimana?" Jurnal Jaffray 10, no. 2 (October 1, 2012): 157-65. https://doi.org/10.25278/jj71.v10i2.57. "Memuji Dengan Nyanyian Dalam Ibadah Jemaat." Jurnal Jaffray 5, no. 1 (01 Desember 2007): 15-19. https://doi.org/10.25278/jj71.v5i1.122.

Sitompul, Einar Martahan. Teologi politik: agama-agama dan kekuasaan. Jakarta: Badan Penelitian dan Pengembangan, Persekutuan Gereja-Gereja di Indonesia, 2004.

Sugiyono, Frans. Mencintai Liturgi. Kanisius, 2010.

“The Wesley Center Online: Charles Wesley.” diakses 24 Juni 2019. http://wesley.nnu.edu/charleswesley/. 
Thomas, Gary L. Sacred Marriage: Bagaimana seandainya Tuhan merancang pernikahan lebih untuk menguduskan kita daripada untuk menyenangkan kita? Yogyakarta: Katalis Media \& Literature - Yayasan Gloria, 2013.

Tong, Stephen. Teologi Penginjilan. Surabaya: Momentum, 2012.

Ulam, Khairul. "Makna Musik Gereja Terhadap Religiusitas Jemaat Umat Kristen (Studi Atas Gereja Ekklesia Kalibata Timur Jakarta Selatan)." Skripsi, S.Ag, Universitas Islam Negeri Jakarta. http://repository.uinjkt.ac.id/dspace/bitstream/123456789/45691/1/KHAIRUL\%20ULAMFUF.pdf

Umrati, and Hengki Wijaya. Analisis Data Kualitatif Teori Konsep dalam Penelitian Pendidikan. Makassar: Sekolah Tinggi Theologia Jaffray, 2020.

Wellem, F. D. Riwayat Hidup Singkat Tokoh-tokoh. Jakarta: BPK Gunung Mulia, 2003.

Wesley, Charles, and Kenneth G. C. Newport. The Sermons of Charles Wesley: A Critical Edition, with Introduction and Notes. Oxford University Press, 2001. 